\title{
TRIBUTE TO ROBERT H. WAGNER
}

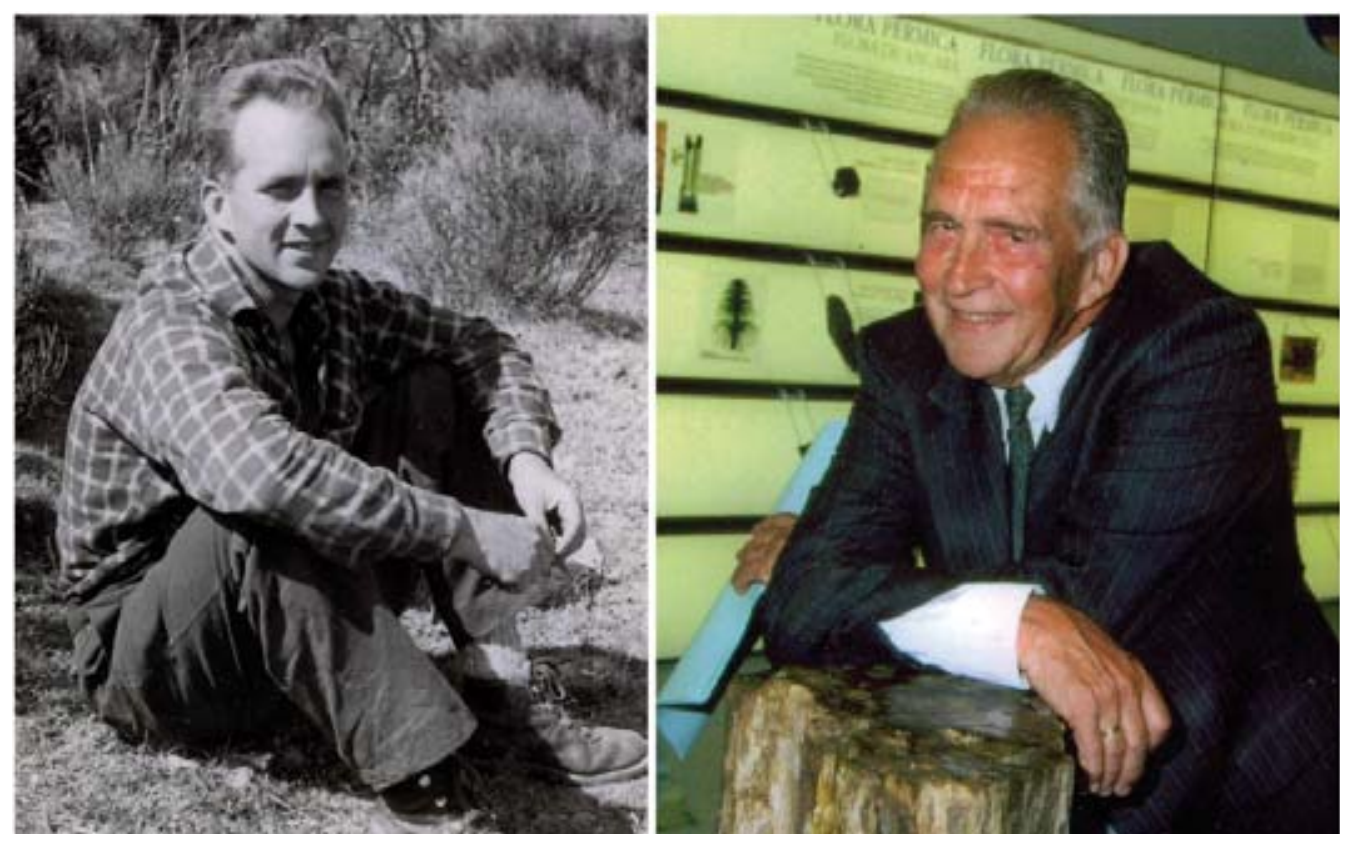

Guest co-editors

Carmen Álvarez-Vázquez

Real Jardín Botánico de Córdoba, Spain

John A. Knight

Real Jardín Botánico de Córdoba, Spain

Christopher J. Cleal

National Museum Wales, Cardiff, UK

https://doi.org/10.7203/sjp.31.1.20381 


\section{ROBERT H. WAGNER}

This volume was conceived by a number of ex-research students of Dr Robert H. Wagner ("Bob" Wagner) as a tribute to his extensive contribution to the Earth Sciences. It includes contributions by many of his research colleagues, former students, and others whose work has been greatly influenced by him. Inevitably, the range of work presented in this volume tends to reflect Bob Wagner's interests and research in palaeontology and stratigraphy. However, support and best wishes have also been proffered by others who have worked with Bob in fields as diverse as sedimentology, and structural and regional interpretation.

Bob Wagner was born in 1927 in the then Dutch East Indies, where he spent his formative years, curtailed by the cathartic experience of internment under the Japanese invasion forces (1942-1945). His subsequent higher education was undertaken at the University of Leiden (1946-1953) where he obtained his first degree in Geology. He then embarked on studies for his doctorate, commencing detailed mapping of the Palaeozoic in the north-east of Palencia, NW Spain, from 1950. This early period of research, under the mentoring of Professor Wilhelm Jongmans of the Geologisch Bureau Heerlen and Professor Bermudo Meléndez of the Universidad Central de Madrid (now Universidad Complutense), was seminal in defining the future course of his lifetime studies. This early period introduced him to the complexity of the late Palaeozoic successions of the Cantabrian Mountains, while the guidance of Professor Jongmans led him to the study and stratigraphical applications of fossil flora. The course of pure research was interrupted by the need for gainful employment, so that between 1954 and 1960 he gained important practical experience, working in the Geologisch Bureau for the Mining District, Heerlen, in the international company Royal Dutch-Shell, and in the Turkish Geological Survey, variously employed as palaeobotanist and palynologist.

In 1960 he commenced an academic career in the Geology Department of the University of Sheffield, first as Lecturer, rising to become Reader, lecturing mainly palaeobotany, invertebrate palaeontology and stratigraphy. In this period he was again able to return to research, culminating in the award of his doctorate in 1968 at the Municipal University of Amsterdam for his thesis "Upper Westphalian and Stephanian species of Alethopteris from Europe, Asia Minor and North America". Between 1960 and 1985 he supervised seven doctoral theses at Sheffield in fields as diverse as palynology, sedimentology, palaeobotany, field mapping and structural interpretation of Palaeozoic strata of the Cantabrian Mountains, and detailed stratigraphic interpretation of Carboniferous successions of Spain and north-western Europe. During this period he also maintained a long term consulting role with the coal-mining company Hullera Vasco Leonesa SA (León, Spain) and led projects on the geological investigation of the Guardo-Cervera Coalfield (NE León - NW Palencia, Spain) and preparation of the geological sheet of Barruelo de Santullán under the Plan MAGNA programme for the Geological Map of Spain, amongst numerous other contracts with the geological services of the Iberian Peninsula.

In 1983 he took early retirement from the University of Sheffield, moving to become Head of the Geological Service of the state-owned coal-mining company ENCASUR, through to 1992. From 1983 he was also engaged in setting up a palaeobotanical laboratory and museum as a part of the newly developed Botanical Garden of Córdoba, and in 2012 was formally designated Honorary Director of the Palaeobotanical Centre. He has continued to be active in research there through to the time of preparation of this volume, with numerous projects still focussed towards the future. During this time he has been an inspiring support, both to formal research workers and to numerous students and non-professional enthusiasts for palaeobotany.

In such a long and intensive professional career it is a challenge to pick out the most outstanding achievements, a task which will always be subjective to the specific experience of any one of his former students, friends or colleagues. All, however, will recognise the great value of his many years of active service to the geological community, taking a leading role in the Subcommission on Carboniferous Stratigraphy (SCCS) of the International Union of Geological Sciences. He became Secretary to the SCCS in 1963, becoming President between 1983 and 1987, and served a further year as Vice-President. During this period he was a principal organiser for a number of meetings of the International Congress on Carboniferous Stratigraphy and Geology and interim meetings of the SCCS. His work with the SCCS was reflected in the preparation of the major reference work "The Carboniferous of the World" (in three volumes 1983, 1985, 1996), of which he was principal coordinator and editor. One of his lasting contributions to Carboniferous 
stratigraphy will be his recognition of important gaps and inconsistencies in the traditional subdivisions of the Carboniferous strata of Western Europe, leading to his initiative in setting up the Cantabrian and Barruelian stages (now accorded sub-stage status) in the West European chronostratigraphic framework and his lead in proposing the Asturian and Saberian substages (currently under evaluation for future ratification). His contribution to the analysis of major geotectonic units is reflected by the recognition of the terranes assembly of the Iberian Massif, which determined that the Iberian Massif did not exist as a unit before the late Carboniferous.

Bob Wagner is also a palaeobotanist of international repute. His early training with Dr W. Jongmans placed him in a line of direct continuity with some of the great figures of Carboniferous palaeobotany including Dr Robert Kidston. His palaeobotanical work includes the extensive systematic documentation of Carboniferous floras, in which he recognised over seventy new taxa, including a number of new genera. A closely related element of his work is the documentation and interpretation of palaeofloristic assemblages and the use of palaeobotanical biostratigraphy, above all for the elucidation of late Carboniferous successions in the geologically complex areas of the Cantabrian Mountains, but also for application throughout the palaeoequatorial belt; his definition of megafloral zones is now widely accepted and applied. However in the context of palaeobotany his outstanding achievement can now be appreciated as the setting up of the Palaeobotanical Centre in the Real Jardín Botánico de Córdoba, which is the centre for conservation and study of the most extensive collections of the Carboniferous fossil floras of the Iberian Peninsula plus other representative European floras, supported by, what is almost certainly, one of the most complete libraries of relevant palaeobotanical literature.

The international significance of the life work of Bob Wagner has been recognised by his investiture in 1984 as Doctor "Honoris Causa" by the University of Córdoba and by the award of the Gold Medal of the Karlovy University, Prague, in 1998. The scope and significance of his professional work has been acknowledged frequently in international publications by his students, colleagues and collaborators. However, by the publication of the present dedicatory volume the editors and contributors wish to place on record the depth of appreciation, both personal and professional, which the geological community shares in recognising the life work of Dr Robert H. Wagner. 
